\title{
Determinan Carbon Emission Disclosure Perusahaan Manufaktur
}

\author{
Luh Gede Krisna Dewi ${ }^{1}$ \\ Made Yenni Latrini ${ }^{2}$ \\ Ni Nyoman Rsi Respati ${ }^{3}$ \\ ${ }^{1,2}$ Fakultas Ekonomi dan Bisnis Universitas Udayana (Unud), Bali, Indonesia \\ e-mail: gede_krisna@unud.ac.id
}

\begin{abstract}
ABSTRAK
Aktivitas perusahaan memiliki andil besar dalam bertambahnya konsentrasi gas karbon di atmosfer bumi. Praktik akuntansi selama ini dinilai oleh beberapa pihak sebagai pemicu terjadinya krisis lingkungan. Sebagai respon atas isu tersebut, perusahaan memberikan perhatian lebih pada upaya pengurangan emisi karbon dan melakukan pengungkapan yang lebih luas terkait dengan hal tersebut. Penelitian ini menggunakan analisis regresi berganda untuk mencari pengaruh economic pressure, social pressure, financial market pressure, regulatory pressure pada luas pengungkapan emisi karbon perusahaan manufaktur yang terdaftar di BEI periode 2012-2016. Hasil analisis data menemukan bahwa regulatory pressure yang diproksikan dengan status kepemilikan perusahaan sebagai BUMN mampu mempengaruhi luas pengungkapan emisi karbon perusahaan manufaktur. Sedangkan faktor tekanan (pressure) yang berasal dari economic, social dan financial market tidak berpengaruh pada luas pengungkapan emisi karbon. Implikasi dari penelitian ini menjadi masukan bagi penyusun standar (standart setter) dalam proses penyusunan dan evaluasi kebijakan terkait dengan pengungkapan sukarela (voluntary disclosure) dalam pelaporan keuangan perusahaan.
\end{abstract}

Kata kunci: Carbon emission disclosure, economic, social, financial market, regulatory pressure.

\footnotetext{
ABSTRACT

Company activities has role in increasing the levels of gas carbon in the atmosphere. Accounting practises assesed by several parties as the trigger for the environmental crisis. As the response, the company began to pay more attention to the effort of the carbon emissions reduction and conduct comprehensive disclosure associated with it. Research uses mutiple regression analysis to seek the effect of economic, social, financial market, and regulatory pressure on the carbon emission disclosure of manufacturing companies listed on the BEI. The result of the data analysis discover that regulatory pressure was able to influence carbon emission disclosure of manufacturing company. While the pressure factor comes from economic, social and financial market has no effect on the area of carbon emission disclosure. The implication of this research become an input for the standard setter in compiling and policies evaluation process with voluntary disclosure in the company's financial report.

Keywords: Carbon emission disclosure, economic, social, financial market, regulatory pressure.
} 
Luh Gede Krisna Dewi, Made Yenni Latrini, dan Ni Nyoman Rsi Respati. Determinan ...

\section{PENDAHULUAN}

Perubahan iklim sebagai dampak dari pemanasan global menjadi isu lingkungan penting dalam beberapa dekade ini. Pemanasan global dipicu oleh efek gas rumah kaca (GRK) yang dihasilkan dari aktivitas manusia. Sejak Revolusi Industri aktivitas manusia memberikan kontribusi bagi peningkatan konsentrasi gas CO2 pada atmosfer bumi (Kalu et.al., 2016). Indonesia memiliki komitmen untuk menurunkan gas rumah kaca (GRK) dengan melibatkan diri dalam United Nation Framework Convention on Climate Change (UNFCCC) mulai tahun 1992 di Rio de Jainero. Partisipasi Indonesia berlanjut dalam amandemen yang dibuat oleh UNFCCC pada tahun 1997 yang dikenal dengan Protokol Kyoto, yakni konvensi internasional yang memuat komitmen negara maju (kelompok Anex 1) untuk mengurangi emisi GRK untuk mencegah peningkatan suhu global dan mengembalikan suhu rata-rata bumi ke kondisi pra industri. Terkendalinya konsentrasi karbon di atmosfer bumi memungkinkan ekosistem beradaptasi terhadap perubahan iklim secara alami, menjamin produksi pangan, dan

memungkinkan pembangunan ekonomi berkelanjutan (Irwhantoko \& Basuki, 2016).

Protokol Kyoto menggunakan tiga mekanisme dalam mengurangi gas rumah kaca (GRK). Ketiga mekanisme tersebut adalah Clean Development Mechanism (CDM), Joint Implementation (JI), dan Emission Trading. Mekanisme Clean Develompment Mechanism dilakukan dengan melibatkan kerjasama antara negara maju (develop countries) dengan negara berkembang (developing countries), dimana negara maju mendanai proyek pembangunan 
yang mengurangi emisi gas rumah kaca (GRK). Sebagai benefit, bagi negara maju akan mendapatkan sertifikat pengurangan emisi (Certified Emission Certificate) sebagai bukti komitmen pengurangan emisi yang diwajibkan dalam Protokol Kyoto. Pada mekanisme Joint Implementation (JI) pengurangan emisi dilakukan melalui kerjasama antar anggota Anex 1 (negara maju) yakni mentransfer atau menerima setiap unit penurunan emisi yang diakibatkan oleh proyek pengurangan emisi dalam setiap sektor ekonomi. Mekanisme ketiga yakni Emission Trading mengatur tentang perdagangan emisi antar negara Anex 1 sebagai upaya pengurangan dan pembatasan emisi karbon.

Pemerintah Indonesia memberikan perhatian serius sebagai tindak lanjut dari keterlibatan dalam UNFCCC. Beberapa regulasi ditetapkan untuk mengatur pengurangan emisi karbon. Undang-undang No. 6 Tahun 1994 yang mengatur tentang tercapainya stabilitas konsensi emisi GRK pada tingkat aman, tanggung jawab bersama sesuai dengan kemampuan, dan bantuan negara maju kepada negara berkembang melalui pendanaan, asuransi dan alih teknologi. Peraturan Presiden No.61 Tahun 2011 tentang Rencana Aksi Nasional Pengurangan Emisi Gas Rumah Kaca yang mengatur pengurangan emisi karbon pada sektor pertanian, kehutanan dan lahan gambut, energi dan transportasi, industri, pengolahan limbah dan kegiatan pendukung lainnya. Melalui regulasi ini pemerintah secara bersama-sama mengajak pelaku usaha untuk mengurangi emisi gas rumah kaca yang ditunjukkan melalui pengungkapan emisi karbon (carbon emission disclosure). 
Luh Gede Krisna Dewi, Made Yenni Latrini, dan Ni Nyoman Rsi Respati. Determinan ...

Praktik pengungkapan emisi karbon (carbon emission disclosure) di Indonesia merupakan pengungkapan yang bersifat sukarela (voluntary disclosure). Pengungkapan yang terkait dengan emisi gas rumah kaca termasuk emisi karbon masih minim dan hanya untuk memenuhi pedoman ISO 14064-1 (Pradini, 2013). Menurut (Berthelot \& Robert, 2011) perusahaan melakukan pengungkapan emisi karbon dengan pertimbangan bahwa dengan adanya informasi ini maka perusahaan akan mendapatkan legitimasi dari stakeholder, mengindari ancaman seperti peningkatan biaya operasional, pengurangan permintaan, risiko reputasi, proses hukum serta denda dan pinalti. Pengungkapan informasi terkait strategi, target, dan proyek yang dilakukan oleh perusahaan untuk mengurangi emisi karbon akan memberikan pemahaman lebih baik bagi investor tentang kinerja perusahaan (Kalu et al., 2016).

Carbon emission disclosure oleh perusahaan dipengaruhi oleh beberapa faktor. Secara garis besar faktor-faktor tersebut dapat diklasifikasikan sebagai faktor economic pressure, social pressure, financial market pressure dan regulatory (institutional) pressure (Kalu et al., 2016). Beberapa penelitian menguji pengaruh karakteristik perusahaan seperti ukuran perusahaan, umur perusahaan, jenis atau tipe industri, profitabilitas, leverage, keikutsertaan dalam meratifikasi Protokol Kyoto (Borghei-Ghomi \& Leung, 2013); (Freedman \& Jaggi, 2005); (Irwhantoko \& Basuki, 2016); (Kalu et al., 2016); (Luo et al., 2012); (Peng et al., 2015); (Pradini, 2013); (Prado-Lorenzo et al., 2009); (Stanny \& Ely, 2008) penerapan good corporate government (Anwar, 2016; Bae Choi et 
al., 2013) dan kinerja lingkungan (Dawkins \& Fraas, 2011) terhadap luas pengungkapan emisi karbon (carbon emission disclosure) perusahaan.

Penelitian ini menganalisis faktor-faktor determinan luas pengungkapan emisi karbon di negara berkembang sesuai dengan penelitian (Kalu et al., 2016) yakni faktor economic pressure, social pressure, financial market pressure dan regulatory pressure. Hal ini sesuai dengan peranan Indonesia sebagai negara berkembang bersama dengan negara India, Cina, Kolombia, Ethiopia, Malaysia, Filipina, Nigeria, dan Afrika Selatan melakukan pengurangan emisi melalui pengembangan kebijakan dan program untuk pembangunan berkelanjutan (sustainable development). Analisis faktor determinan ini akan dilengkapi dengan beberapa teori yang melandasi masing-masing faktor seperti teori sinyal yang menjelaskan dari sisi economic pressure, teori legitimasi menjelaskan dari sisi social pressure, teori agensi menjelaskan dari sisi financial market pressure, dan teori stakeholder menjelaskan dari sisi regulatory pressure.

Faktor pertama yang mempengaruhi luas pengungkapan emisi karbon berasal dari economic pressure. Perusahaan mempunyai motivasi untuk mengungkapkan informasi terkait emisi karbon sebagai sebagai upaya peningkatan citra perusahaan di lingkungannya (Kalu et al., 2016). Perusahaan berusaha menampilkan citra ramah lingkungan (green business), melakukan pengurangan penggunaan energi dan biaya, dan secara proaktif melakukan pengungkapan "good news". Hal ini dilakukan untuk mendapatkan reputasi baik di pandangan investor. 
Luh Gede Krisna Dewi, Made Yenni Latrini, dan Ni Nyoman Rsi Respati. Determinan ...

Pengaruh variabel ekonomi terhadap upaya pengurangan emisi karbon ini terkait dengan biaya operasional yang berdampak pada jumlah laba yang dihasilkan (Kalu et al., 2016). Beberapa negara menekan pelaku bisnis untuk berpartisipasi dalam upaya pengurangan emisi karbon dengan mengenakan tambahan biaya, fee, atau pajak pada emisi karbon yang dihasilkan, sehingga hal ini penting untuk dipertimbangkan dalam pengambilan keputusan operasional. Menurut (Jannah, 2014) perusahaan yang memiliki kinerja keuangan yang lebih baik memiliki potensi yang lebih besar dalam mengungkapkan informasi lingkungan. Hal ini sejalan dengan penelitian (Bae Choi et al., 2013) yang menemukan bahwa perusahaan dengan kinerja keuangan baik memiliki kemampuan lebih untuk membayar tambahan sumber daya manusia dan finansial yang diperlukan untuk pengungkapan sukarela, termasuk pengungkapan emisi karbon.

Perusahaan yang memiliki kinerja keuangan lebih baik akan memiliki kemungkinan lebih besar untuk mengurangi emisi karbon dalam aktivitas perusahaannya (Pradini, 2013). Perusahaan yang memiliki kinerja keuangan baik memiliki kemampuan yang lebih besar berkontribusi dalam pelestarian lingkungan seperti menggunakan mesin-mesin produksi yang ramah lingkungan, penanaman pohon untuk mencegah polusi, dan pengurangan emisi karbon untuk kualitas udara yang lebih baik (Irwhantoko \& Basuki, 2016). Kinerja perusahaan juga mempengaruhi kecepatan respon perusahaan terhadap tekanan eksternal (Jannah, 2014). Respon terhadap tekanan eksternal ini ditunjukkan dengan memberikan pengungkapan yang lebih cepat dan luas terkait emisi karbon 
sebagai sinyal bahwa perusahaan memiliki komitmen untuk penyelamatan lingkungan. Penelitian ini menggunakan tingkat profitabilitas yang diukur dengan return on asset (ROA) sebagai proksi dari kinerja keuangan perusahaan. Hipotesis pertama penelitian ini adalah:

$\mathrm{H}_{1}$ : economic pressure berpengaruh positif pada pengungkapan emisi karbon perusahaan di Indonesia.

Faktor berikutnya yang mempengaruhi luas pengungkapan emisi karbon adalah social pressure. Social pressure adalah permintaan dan harapan masyarakat terhadap aktivitas perusahaan sebagai bagian dari komunitas masyarakat (Kalu et al., 2016). Masyarakat berharap perusahaan mengurangi emisi karbon dan melakukan pengungkapan terkait emisi karbon karena berhubungan dengan perubahan iklim. Jika perusahaan mengabaikan tekanan masyarakat tersebut, hal ini menimbulkan kesan bahwa manajemen perusahaan tidak memiliki cukup perhatian dan kepedulian terhadap penyelamatan lingkungan, serta tidak memiliki rencana untuk mengurangi risiko pencemaran. Teori legitimasi menyarankan pengungkapan untuk meyakinkan masyarakat bahwa terdapat kesesuaian antara nilai yang diterapkan perusahaan dengan nilai yang dianut dalam masyarakat (Irwhantoko \& Basuki, 2016).

Lebih lanjut temuan penelitian Irwhantoko \& Basuki (2016) menjelaskan bahwa legitimasi perusahaan akan terancam jika terdapat perbedaan antara nilai yang dianut oleh masyarakat dengan nilai yang diterapkan dalam perusahaan. Sehingga melalui pengungkapan perusahaan berusaha meyakinkan masyarakat bahwa aktivitas yang dilakukan oleh perusahaan tidak bertentangan dengan norma dan aturan yang berlaku. Perusahaan memiliki kewajiban moral untuk 
Luh Gede Krisna Dewi, Made Yenni Latrini, dan Ni Nyoman Rsi Respati. Determinan ...

menyampaikan informasi kepada masyarakat, tidak hanya informasi keuangan saja, namun juga informasi sosial dan lingkungan (Jannah, 2014). Pencapaian kinerja lingkungan yang baik merupakan respon perusahaan terhadap harapan dan tekanan masyarakat terkait dengan komitmen perusahaan dalam pelestarian lingkungan. Masyarakat mengharapkan perusahaan mampu menyelaraskan antara norma dan aturan yang berlaku di perusahaan dengan norma dan aturan yang berkembang di mayarakat (Suhardi \& Purwanto, 2015). Penelitian ini menggunakan kinerja lingkungan sebagai proksi dari social pressure. Perusahaan dengan kinerja lingkungan yang lebih baik memiliki insentif untuk lebih proaktif menangani masalah lingkungan (Suhardi \& Purwanto, 2015). Hipotesis kedua penelitian ini adalah:

$\mathrm{H}_{2}$ : social pressure berpengaruh positif pada pengungkapan emisi karbon perusahaan di Indonesia.

Faktor selanjutnya yang mempengaruhi luas pengungkapan emisi karbon perusahaan adalah financial market pressure. Perusahaan memiliki tanggung jawab kepada investor dan kreditur, untuk melakukan pengungkapan baik kinerja keuangan maupun kinerja lingkungan, sebagai pertimbangan dalam pengambilan keputusan investasi (Kalu et al., 2016). Terkait dengan hal tersebut, perusahaan dengan sumber pendanaan eksternal tinggi memiliki kemungkinan melakukan pengungkapan sukarela secara lebih luas. Investor memiliki peranan penting bagi perusahaan terutama bagi perusahaan yang memiliki keterbatasan sumber pendanaan untuk eksistensi dan pengembangan perusahaan. Untuk mendapatkan perhatian investor, perusahaan akan bersedia mengungkapkan informasi penting, terutama informasi yang bersifat positif. Salah satunya adalah informasi 
mengenai upaya perusahaan mengurangi emisi karbon, sehingga hal ini menjadi pertimbangan dalam keputusan investasi. Penelitian ini menggunakan tingkat leverage sebagai faktor financial market pressure yang mempengaruhi luas pengungkapan emisi karbon perusahaan. Hipotesis ketiga penelitian ini adalah:

$\mathrm{H}_{3}$ : financial market pressure berpengaruh positif pada pengungkapan emisi karbon perusahaan di Indonesia.

Faktor terakhir yang mempengaruhi luas pengungkapan emisi karbon perusahaan yang dianalisis dari penelitian ini adalah regulatory pressure. Pemerintah sebagai salah satu stakeholder perusahaan berperan sebagai pengawas aktivitas perusahaan. Melalui beberapa regulasi yang telah ditetapkan, pemerintah berupaya menekan pelaku usaha untuk meningkatkan kesadaran dan kepedulian terhadap lingkungan. Menurut (Suhardi \& Purwanto, 2015) pemerintah memiliki kewenangan besar untuk menekan perusahaan agar bertanggung jawab terhadap pelestarian lingkungan dan melakukan pengungkapan emisi karbon. Beberapa penelitian menunjukkan bahwa perusahaan menggunakan pengungkapan untuk mengurangi kemungkinan ancaman regulasi dan dampak negatif lainnya pada aktivitas operasi perusahaan (Peters \& Romi, 2009). Tekanan dari regulator (pemerintah) merupakan salah satu faktor utama perusahaan peduli terhadap lingkungan dan melakukan pengungkapan emisi karbon (Peng et al., 2015). Penelitian ini menggunakan status perusahaan sebagai BUMN sebagai proksi dari regulatory pressure yang mempengaruhi luas pengungkapan emisi karbon. Hipotesis keempat dari penelitian ini adalah: 
Luh Gede Krisna Dewi, Made Yenni Latrini, dan Ni Nyoman Rsi Respati. Determinan ...

$\mathrm{H}_{4}$ : regulatory pressure berpengaruh positif pada pengungkapan emisi karbon perusahaan di Indonesia

Penelitian ini juga secara spesifik menganalisis pengaruh masing-masing faktor determinan (economic pressure, social pressure, financial market pressure, regulatory pressure) terhadap luas pengungkapan emisi karbon dan dikaitkan dengan teori-teori yang menjustifikasi temuan penelitian seperti teori agensi, legitimasi, sinyal, dan stakeholder.

Teori sinyal menjelaskan tentang kesulitan dalam menyeimbangkan informasi yang dimiliki oleh manajemen dengan investor. Asimetri informasi timbul ketika informasi yang tersedia bagi manajemen perusahaan dan investor tidak terdistribusi secara merata (Healy \& Palepu, 2001). Sehingga pengungkapan informasi memiliki peranan penting untuk mengurangi asimetri informasi. Teori sinyal menjelaskan bahwa pengungkapan informasi perusahaan bertujuan untuk menunjukkan kinerja baik perusahaan, memperkenalkan diri ke publik, dan mengurangi asimetri informasi sehingga meningkatkan reputasi dan opini publik terhadap perusahaan (Kalu et al., 2016).

Legitimasi yang ingin didapatkan oleh perusahaan dari masyarakat adalah bahwa aktivitas operasi perusahaan telah sesuai dengan batasan-batasan dan norma sesuai dengan ketentuan yang berlaku (Deegan \& Unerman, 2011). Legitimasi akan diperoleh perusahaan jika antara perusahaan dengan masyarakat terdapat persamaan hasil yang diharapkan. Teori legitimasi terfokus pada hubungan antara perusahaan dengan masyarakat melalui peraturan yang dibuat oleh pemerintah (Irwhantoko \& Basuki, 2016). Teori ini mampu menjelaskan motivasi pengungkapan lingkungan oleh suatu organisasi. 
Teori keagenan menekankan pada pentingnya pemilik perusahaan menyerahkan pengelolaan perusahaan kepada pihak-pihak yang memiliki kemampuan professional mengelola perusahaan dengan baik (Asri \& Ulupui, 2017). Sebagai upaya mengurangi konflik keagenan, pemiliki perusahaan melakukan upaya bonding dengan melibatkan investor dan kreditur sebagai pihak yang mengawasi kinerja manajemen. Perusahaan memiliki tanggung jawab kepada investor dan kreditur, untuk melakukan pengungkapan baik kinerja keuangan maupun kinerja lingkungan, sebagai pertimbangan bagi investor dalam pengambilan keputusan investasi (Kalu et al., 2016).

Perspektif dalam teori stakeholder menjelaskan bahwa perusahaan beroperasi bukan hanya untuk kepentingan sendiri, namun harus memberikan manfaat bagi stakeholder. Sebaliknya, keberadaan suatu perusahaan sangat dipengaruhi oleh dukungan yang diberikan oleh stakeholder kepada perusahaan tersebut. Berdasarkan teori stakeholder, kelompok stakeholder yang berbeda mempunyai pandangan yang berbeda mengenai bagaimana sebuah organisasi sebaiknya melakukan operasinya, berbagai kontrak sosial akan “dinegosiasikan" dengan kelompok stakeholder yang berbeda bukan suatu kontrak dengan masyarakat secara umum seperti yang dinyatakan teori legitimasi (Deegan \& Unerman, 2011).

Emisi karbon adalah pelepasan gas karbon ke atmosfer bumi. Carbon Emission Disclosure merupakan salah satu contoh dari pengungkapan lingkungan yang merupakan bagian dari laporan tambahan dan diluar ruang lingkup Standar Akuntansi Keuangan. Pengungkapan lingkungan mencakup intensitas GHG 
Luh Gede Krisna Dewi, Made Yenni Latrini, dan Ni Nyoman Rsi Respati. Determinan ...

emissions atau gas rumah kaca dan penggunaan energi, corporate governance dan strategi dalam kaitannya dengan perubahan iklim, kinerja terhadap target pengurangan emisi gas rumah kaca, risiko dan peluang terkait dampak perubahan iklim (Cotter \& Najah, 2012).

Pengaruh tekanan ekonomi (economic pressure) adalah motivasi perusahaan untuk mengurangi penggunaan energi dan biaya emisi karbon sehingga meningkatkan profitabilitas perusahaan (Kalu et al., 2016). Tekanan sosial (social pressure) adalah permintaan dan harapan masyarakat terhadap aktivitas perusahaan sebagai bagian dari komunitas masyarakat (Kalu et al., 2016). Tekanan pasar keuangan (financial market pressure) berasal dari investor yang mengharapkan perusahaan bersedia mengungkapkan informasi penting terutama informasi yang positif sebagai upaya mengurangi asimetri informasi (Kalu et al., 2016). Tekanan regulator (regulatory pressure) merupakan faktor pendorong bagi aktivitas pengurangan dan pengungkapan emisi karbon yang berasal dari peraturan pemerintah (regulator). Pemerintah memaksa pelaku bisnis untuk mengurangi emisi karbon dengan beberapa regulasi seperti misalnya Peraturan Presiden No.61 Tahun 2011 tentang Rencana Aksi Nasional Pengurangan Emisi Gas Rumah Kaca.

Penelitian mengenai pengungkapan emisi karbon mulai berkembang seiring dengan semakin meningkatnya perhatian global terhadap perubahan iklim dunia. Perubahan iklim dinilai mempengaruhi kegiatan bisnis perusahaan, salah satunya adalah biaya pengurangan emisi karbon yang harus ditanggung perusahaan. Penelitian-penelitian sebelumnya meneliti berbagai faktor yang 
mempengaruhi pengungkapan emisi karbon perusahaan sebagai bentuk tanggung jawab dan komitmen terhadap lingkungan. Beberapa penelitian menguji pengaruh karakteristik perusahaan seperti ukuran perusahaan, umur perusahaan, jenis atau tipe industri, profitabilitas, leverage, keikutsertaan dalam meratifikasi Protokol Kyoto (Borghei-Ghomi \& Leung, 2013); (Freedman \& Jaggi, 2005); (Irwhantoko \& Basuki, 2016); (Kalu et al., 2016); Luo et al., 2012); (Peng et.al., 2015); (Pradini, 2013); (Prado-Lorenzo et al., 2009); (Stanny \& Ely, 2008) penerapan good corporate government (Anwar, 2016; Bae Choi et al., 2013) dan kinerja lingkungan (Dawkins \& Fraas, 2011) terhadap luas pengungkapan emisi karbon (carbon emission disclosure) perusahaan. Berdasarkan pemaparan tersebut diatas ada 4 (empat) hipotesis yang diajukan dalam usulan penelitian ini:

\section{METODE PENELITIAN}

Penelitian ini dilakukan di pasar modal Indonesia. Populasi dalam penelitian ini adalah perusahaan yang terdaftar di Bursa Efek Indonesia periode 2012-2016. Penelitian ini akan menggunakan perusahaan manufaktur sebagai sampel penelitian dikarenakan perusahaan manufaktur termasuk ke dalam salah satu sektor yang harus mengurangi emisi karbon sesuai dengan Perpres No.61 Tahun 2011 tentang Rencana Aksi Nasional Pengurangan Emisi Gas Rumah Kaca. Pengambilan sampel (sampling) dari populasi yang ada dilakukan secara purposive sampling dengan tujuan mendapatkan sampel yang representatif sesuai dengan kriteria yang ditentukan. Berdasarkan kriteria yang ditetapkan, diperoleh 16 (enam belas) perusahaan yang menjadi sampel penelitian (Lampiran 1). 
Luh Gede Krisna Dewi, Made Yenni Latrini, dan Ni Nyoman Rsi Respati. Determinan ...

Dengan jumlah tahun pengamatan 5 (lima) tahun, maka keseluruhan sampel berjumlah 80 (delapan puluh) sampel.

\section{Tabel 1.}

Pemilihan Sampel

\begin{tabular}{clc}
\hline No. & \multicolumn{1}{c}{ Kriteria } & Jumlah Perusahaan \\
\hline 1. & Perusahan manufaktur di BEI tahun 2012-2016 & 124 \\
2. & Perusahaan yang tidak melakukan pengungkapan & $(105)$ \\
& emisi karbon & $(3)$ \\
3. & Tidak ada data dalam peringkat PROPER & 16 \\
Jumlah sampel akhir & 5 \\
Tahun Pengamatan & 80 \\
Jumlah Pengamatan
\end{tabular}

Sumber : Data diolah, 2018

Pengungkapan emisi karbon diukur dengan menggunakan delapan belas (18) item pengungkapan yang diadopsi dari penelitian Choi et. al (2013) yakni: risiko dan peluang perubahan iklim (CC/Climate Change), emisi gas rumah kaca (GHG/Greenhouse Gas), konsumsi energi (EC/Energy Consumption), pengurangan gas rumah kaca dan biaya ( $\mathrm{RC} /$ Reduction and Cost) serta akuntabilitas emisi karbon (AEC/Accountability of Emission Carbon). Economic pressure dengan proksi profitabilitas diukur dengan tingkat ROA yakni perbandingan antara laba bersih dengan total asset perusahaan pada periode tertentu (Jannah, 2014). Social pressure dalam penelitian ini diproksikan dengan kinerja lingkungan. Kinerja lingkungan diukur dengan menggunakan peringkat PROPER dari Kementerian Lingkungan Hidup (Jannah, 2014). Financial market pressure diproksikan dengan leverage diukur dengan menggunakan rasio total utang dengan total asset perusahaan (Jannah, 2014). Regulatory pressure diukur dengan membedakan antara perusahaan BUMN dan perusahaan swasta. Perusahaan BUMN diberikan skor 1 dan perusahaan swasta diberikan skor 0 (Luo et al., 2012). Teknik analisis yang akan digunakan dalam penelitian ini 
adalah analisis regresi linear berganda. Teknik analisis regresi linier berganda menggunakan program Statistical Product and Service Solution (SPSS). Tahapan analisis pada penelitian ini yakni, uji asumsi klasik, analisis regresi linier berganda, koefisien determinasi, uji keseuaian model dan uji parsial.

\section{HASIL DAN PEMBAHASAN}

Uji regresi linier berganda menggunakan software SPSS Versi 13 dengan tingkat signifikansi 0,05. Analisis regresi akan memperlihatkan sejauh mana pengaruh variabel independen terhadap variabel dependen. Model regresi linear dapat dibentuk dengan melihat nilai koefisien regresi $(\beta)$ masing-masing variabel independen.

Tabel 2.

Hasil Analisis Regresi Linear

\begin{tabular}{|c|c|c|c|c|c|}
\hline \multirow[b]{2}{*}{ Model } & \multicolumn{2}{|c|}{$\begin{array}{c}\text { Unstandardized } \\
\text { Coefficients }\end{array}$} & \multirow{2}{*}{$\begin{array}{c}\text { Standardized } \\
\text { Coefficients } \\
\text { Beta }\end{array}$} & \multirow[b]{2}{*}{$T$} & \multirow[b]{2}{*}{ Sig. } \\
\hline & $\mathrm{B}$ & Std. Error & & & \\
\hline $\begin{array}{ll}1 & \text { (Constant) }\end{array}$ & 2,529 & 2,253 & & 1,123 & 0,265 \\
\hline Economic pressure (ROA) & $-1,242$ & 2,879 & $-0,047$ & $-0,431$ & 0,668 \\
\hline Social pressure (PROP) & 0,471 & 0,609 & 0,089 & 0,773 & 0,442 \\
\hline Financial market pressure (LEV) & $-2,424$ & 1,564 & -0.149 & $-1,550$ & 0,125 \\
\hline Regulatory pressure (REG) & 4,928 & 0,787 & 0,575 & 6,258 & 0,000 \\
\hline$F=11,592$ & & & & & \\
\hline Sig.F $=0,000$ & & & & & \\
\hline Ajusted R Square $=0,349$ & & & & & \\
\hline
\end{tabular}

Hasil analisis regresi pada Tabel 2, menghasilkan persamaan regresi yang dapat dirumuskan sebagai berikut.

$$
\mathrm{CED}=2,529-1,242 \mathrm{ROA}+0,471 \mathrm{PROP}-2,424 \mathrm{LEV}+4,928 \mathrm{REG}
$$

Nilai konstanta $(\alpha)$ sebesar 2,529 menunjukkan bahwa apabila economic pressure (ROA), social pressure (PROP), financial market pressure (LEV) dan regulatory pressure (REG) sama dengan nol, maka nilai pengungkapan emisi 
Luh Gede Krisna Dewi, Made Yenni Latrini, dan Ni Nyoman Rsi Respati. Determinan ...

karbon (CED) cenderung meningkat sebesar 2,529. Nilai koefisien regresi $\left(\beta_{1}\right)$ pada variabel economic pressure (ROA) sebesar -1,242. Koefisien regresi yang bernilai negatif memiliki arti jika tingkat economic pressure yang diukur dengan ROA meningkat sebesar satu satuan, maka luas pengungkapan emisi karbon (CED) akan mengalami penurunan sebesar 1,242 satuan dengan asumsi variabel lainnya cateris paribus. Nilai koefisien regresi $\left(\beta_{2}\right)$ pada variabel social pressure (PROP) sebesar 0,471. Koefisien regresi yang bernilai positif memiliki arti jika tingkat social pressure yang diukur dengan peringkat PROPER meningkat sebesar satu satuan, maka luas pengungkapan emisi karbon (CED) akan mengalami peningkatan sebesar 0,471 satuan dengan asumsi variabel lainnya cateris paribus. Nilai koefisien regresi $\left(\beta_{3}\right)$ pada variabel financial market pressure (LEV) sebesar $-2,424$. Koefisien regresi yang bernilai negatif memiliki arti jika tingkat financial market pressure yang diukur dengan leverage meningkat sebesar satu satuan, maka luas pengungkapan emisi karbon (CED) akan mengalami penurunan sebesar 2,424 satuan dengan asumsi variabel lainnya cateris paribus. Nilai koefisien regresi $\left(\beta_{4}\right)$ pada variabel regulatory pressure (REG) sebesar 4,928. Koefisien regresi yang bernilai positif memiliki arti jika tingkat regulatory pressure yang diukur dengan status perusahaan BUMN meningkat sebesar satu satuan, maka luas pengungkapan emisi karbon (CED) akan mengalami peningkatan sebesar 4,928 satuan dengan asumsi variabel lainnya cateris paribus.

Koefisien determinasi $\left(\mathrm{R}^{2}\right)$ pada intinya mengukur seberapa jauh kemampuan model dalam menerangkan variasi variabel dependen. Untuk 
menghindari bias terhadap jumlah variabel independen yang dimasukkan ke dalam model, maka penelitian ini menggunakan nilai Adjusted $R^{2}$.

Hasil pengujian pada Tabel 2 menunjukkan nilai Adjusted $R^{2}$ adalah sebesar 0,349 atau 34,9 persen. Angka ini menunjukkan bahwa sebesar 34,9 persen variabilitas pengungkapan emisi karbon dipengaruhi economic pressure (tingkat ROA perusahaan), social pressure (kinerja lingkungan yang diukur dari peringkat PROPER), financial market pressure (tingkat leverage perusahaan), dan regulatory pressure (status perusahaan BUMN atau swata). Sisanya sebesar 65,1 persen variabilitas pengungkapan emisi karbon dipengaruhi oleh variabel lain yang tidak diteliti dalam penelitian ini.

Uji statistik F pada dasarnya menunjukkan apakah semua variabel bebas yang dimasukkan dalam model mempunyai pengaruh secara simultan terhadap variabel terikat. Hasil pengujian pada Tabel 2 menunjukkan $F_{\text {hitung }}$ sebesar 11,592 dengan signifikansi sebesar 0,000 lebih kecil dari 0,05. Hal ini menunjukkan bahwa semua variabel bebas secara simultan merupakan penjelas yang signifikan pada variabel terikat.

Uji $\mathrm{t}$ dilakukan untuk mengetahui seberapa besar pengaruh variabel independen pada variabel dependen secara individual. Uji $t$ dengan membandingkan nilai signifikansi yang dihasilkan dengan taraf signifikansi $(\alpha)$ 0,05. Kriteria penetapan keputusan yakni apabila tingkat signifikansi $\mathbf{t} \leq 0,05$ maka hipotesis diterima, namun apabila tingkat signifikansi $t>0,05$ maka hipotesis ditolak. Hasil uji t berdasarkan Tabel 2 dapat diinterpretasikan hasil sebagai berikut. 
Luh Gede Krisna Dewi, Made Yenni Latrini, dan Ni Nyoman Rsi Respati. Determinan ...

Hipotesis pertama menyatakan bahwa economic pressure berpengaruh positif pada pengungkapan emisi karbon perusahaan di Indonesia. Hasil pengujian menunjukkan variabel economic pressure yang diukur dengan tingkat profitabilitas perusahaan (ROA) memiliki koefisien regresi negatif sebesar 1,242 dengan tingkat signifikansi 0,668 lebih besar dari $\alpha(5 \%)$. Hasil tersebut menunjukkan bahwa economic pressure tidak berpengaruh pada pengungkapan emisi karbon perusahaan di Indonesia atau dengan kata lain $\mathrm{H}_{1}$ ditolak.

Hipotesis kedua menyatakan bahwa social pressure berpengaruh positif pada pengungkapan emisi karbon perusahaan di Indonesia. Hasil pengujian menunjukkan variabel social pressure yang diukur dengan peringkat PROPER perusahaan memiliki koefisien regresi positif sebesar 0,471 dengan tingkat signifikansi 0,442 lebih besar dari $\alpha(5 \%)$. Hasil tersebut menunjukkan bahwa social pressure tidak berpengaruh pada pengungkapan emisi karbon perusahaan di Indonesia atau dengan kata lain $\mathrm{H}_{2}$ ditolak.

Hipotesis ketiga menyatakan bahwa financial market pressure berpengaruh positif pada pengungkapan emisi karbon perusahaan di Indonesia. Hasil pengujian menunjukkan variabel financial market pressure yang diukur dengan tingkat leverage perusahaan memiliki koefisien regresi negatif sebesar 2,424 dengan tingkat signifikansi 0,125 lebih besar dari $\alpha(5 \%)$. Hasil tersebut menunjukkan bahwa financial market pressure tidak berpengaruh pada pengungkapan emisi karbon perusahaan di Indonesia atau dengan kata lain $\mathrm{H}_{3}$ ditolak. 
Hipotesis keempat menyatakan bahwa regulatory pressure berpengaruh positif pada pengungkapan emisi karbon perusahaan di Indonesia. Hasil pengujian menunjukkan variabel regulatory pressure yang diukur dengan dummy status perusahaan BUMN atau swasta memiliki koefisien regresi positif sebesar 4,928 dengan tingkat signifikansi 0,000 lebih kecil dari $\alpha(5 \%)$. Hasil tersebut menunjukkan bahwa regulatory pressure berpengaruh positif signifikan pada pengungkapan emisi karbon perusahaan di Indonesia atau dengan kata lain $\mathrm{H}_{4}$ diterima. Hal ini berarti bahwa semakin besar kepemilikan saham oleh pemerintah dalam perusahaan maka semakin tinggi luas pengungkapan emisi karbon oleh perusahaan manufaktur di Indonesia.

Hipotesis pertama penelitian ini menyatakan bahwa economic pressure berpengaruh positif pada pengungkapan emisi karbon perusahaan di Indonesia. Hasil pengujian menunjukkan variabel economic pressure yang diukur dengan tingkat profitabilitas perusahaan (ROA) memiliki koefisien regresi negatif sebesar 1,242 dengan tingkat signifikansi 0,668 lebih besar dari $\alpha(5 \%)$. Hasil tersebut menunjukkan bahwa economic pressure tidak berpengaruh pada pengungkapan emisi karbon perusahaan di Indonesia atau dengan kata lain $\mathrm{H}_{1}$ ditolak. Hasil penelitian ini sejalan dengan penelitian Freedman, M., \& Jaggi, B. (2005); Stanny, E., \& Ely, K. (2008) Prado-Lorenzo, et.al (2009) dan Irwhantoko, I., \& Basuki, B. (2016). Temuan penelitian ini secara teoritis belum mendukung teori sinyal. Teori sinyal menyebutkan bahwa perusahaan melakukan pengungkapan informasi dengan tujuan untuk menunjukkan kinerja baik perusahaan, memperkenalkan diri ke publik, dan mengurangi asimetri informasi sehingga meningkatkan reputasi 
Luh Gede Krisna Dewi, Made Yenni Latrini, dan Ni Nyoman Rsi Respati. Determinan ...

dan opini publik terhadap perusahaan (Kalu et al., 2016). Pengungkapan informasi ini termasuk pengungkapan terkait emisi karbon perusahaan dan kualitas energi yang digunakan serta proses produksi yang dilakukan oleh perusahaan. Pengurangan emisi karbon dan peningkatan kualitas energi dan proses produksi memberikan dampak pada pengurangan biaya operasional dan peningkatan profitabilitas. Hasil penelitian ini menemukan bahwa profitabilitas perusahaan yang diukur dengan tingkat ROA tidak mampu menjadi faktor penentu luas pengungkapan emisi karbon perusahaan dari sisi tekanan ekonomis (economic pressure). Temuan ini berkaitan dengan kondisi perusahaan yang memiliki tingkat profitabilitas tinggi namun sedikit melakukan pengungkapan emisi karbon atau sebaliknya ada perusahaan yang tingkat profitabilitasnya rendah namun melakukan pengungkapan emisi karbon yang luas (Irwhantoko, I., \& Basuki, B., 2016). Hasil penelitian ini juga mengindikasikan bahwa perusahaan yang melakukan pengurangan emisi karbon dan berusaha meningkatkan kualitas energi dan proses produksi yang dijalankan, memerlukan biaya lingkungan yang lebih besar. Peningkatan biaya lingkungan dianggap tidak memberikan manfaat atau keuntungan lingkungan yang lebih besar bagi perusahaan.

Hipotesis kedua penelitian ini menyatakan bahwa social pressure berpengaruh positif pada pengungkapan emisi karbon perusahaan di Indonesia. Hasil pengujian menunjukkan variabel social pressure yang diukur dengan peringkat PROPER perusahaan memiliki koefisien regresi positif sebesar 0,471 dengan tingkat signifikansi 0,442 lebih besar dari $\alpha(5 \%)$. Hasil tersebut menunjukkan bahwa social pressure tidak berpengaruh pada pengungkapan emisi 
karbon perusahaan di Indonesia atau dengan kata lain $\mathrm{H}_{2}$ ditolak. Hasil penelitian ini sejalan dengan penelitian Pradini (2013) Jannah (2014) Madjid \& Ghozali (2015). Perusahaan dengan peringkat PROPER yang tinggi memandang tidak perlu untuk melakukan pengungkapan emisi karbon karena menilai kinerja mereka sudah baik dalam rangka pengurangan emisi gas karbon. Sedangkan perusahaan dengan peringkat yang rendah cenderung berusaha mendapatkan kepercayaan masyarakat sehingga secara sukarela mengungkapkan hasil kinerja lingkungannya. Temuan penelitian ini sesuai dengan teori legitimasi yang menyebutkan bahwa perusahaan ingin mendapatakan legitimasi dari masyarakat dan kepercayaan atas aktivitas operasi perusahaan yang telah sesuai dengan batasan-batasan dan norma sesuai dengan ketentuan yang berlaku. Masyarakat memiliki kemampuan untuk menilai aktivitas perusahaan apakah telah sesuai dengan norma dan aturan yang berlaku di masyarakat, melalui pengungkapan yang dilakukan perusahaan. Sehingga faktor social pressure yang diukur dari peringkat PROPER tidak menjadi penentu luas pengungkapan emisi karbon, namun lebih dikarenakan perusahaan ingin mendapatkan legitimasi dan kepercayaan dari masyarakat melalui pengungkapan informasi terkait aktivitas perusahaan terutama pengurangan emisi karbon.

Hipotesis ketiga menyatakan bahwa financial market pressure berpengaruh positif pada pengungkapan emisi karbon perusahaan di Indonesia. Hasil pengujian menunjukkan variabel financial market pressure yang diukur dengan tingkat leverage perusahaan memiliki koefisien regresi negatif sebesar 2,424 dengan tingkat signifikansi 0,125 lebih besar dari $\alpha(5 \%)$. Hasil tersebut menunjukkan 
Luh Gede Krisna Dewi, Made Yenni Latrini, dan Ni Nyoman Rsi Respati. Determinan ...

bahwa financial market pressure tidak berpengaruh pada pengungkapan emisi karbon perusahaan di Indonesia atau dengan kata lain $\mathrm{H}_{3}$ ditolak. Hasil penelitian ini sejalan dengan penelitian Luo et al.. (2012); Peng et al., (2015); Suhardi, R.P. \& A. Purwanto. (2015) dan Nur Pratiwi (2017). Secara teoritis hasil penelitian ini tidak sesuai dengan teori keagenan. Teori keagenan menyebutkan bahwa pemisahan peran prinsipal dan agen rentan menimbulkan konflik keagenan karena manajemen sebagai pengelola (agen) memiliki keinginan sendiri, dan bertindak untuk memenuhi keinginan pribadinya. Sebagai upaya mengurangi konflik tersebut, pemilik (prinsipal) perusahaan melakukan upaya bonding dengan melibatkan investor dan kreditur sebagai pihak yang mengawasi kinerja manajemen. Perusahaan memiliki tanggung jawab kepada investor dan kreditur, untuk melakukan pengungkapan baik kinerja keuangan maupun kinerja lingkungan, sebagai pertimbangan bagi investor dalam pengambilan keputusan investasi. Temuan penelitian ini menyebutkan bahwa faktor financial market pressure yang diukur dengan tingkat leverage perusahaan bukan merupakan faktor penentu luas pengungkapan emisi karbon perusahaan di Indonesia. Adanya hubungan baik antara perusahaan dengan debtholders menjadi alasan utama perusahaan merasa tidak perlu melakukan pengungkapan informasi lingkungan yang lebih luas (Nur Pratiwi, 2017). Debtholders tidak memperhatikan apakah perusahaan telah melakukan pengungkapan emisi karbon secara memadai atau tidak, dan cenderung lebih memperhatikan faktor-faktor keuangan saja. Tingkat leverage tinggi juga memberikan tekanan kepada perusahaan untuk memberikan perhatian yang lebih besar kepada faktor-faktor yang bersifat ekonomi daripada 
faktor sosial dan lingkungan. Selain hal tersebut, semua perusahaan dengan tingkat leverage tinggi ataupun rendah memiliki kehati-hatian dalam melakukan pengungkapan emisi karbon karena akan menambah biaya operasional dan dianggap membebani perusahaan.

Hipotesis keempat menyatakan bahwa regulatory pressure berpengaruh positif pada pengungkapan emisi karbon perusahaan di Indonesia. Hasil pengujian menunjukkan variabel regulatory pressure yang diukur dengan dummy status perusahaan BUMN atau swasta memiliki koefisien regresi positif sebesar 4,928 dengan tingkat signifikansi 0,000 lebih kecil dari $\alpha(5 \%)$. Hasil tersebut menunjukkan bahwa regulatory pressure berpengaruh positif signifikan pada pengungkapan emisi karbon perusahaan di Indonesia atau dengan kata lain $\mathrm{H}_{4}$ diterima. Hal ini berarti bahwa semakin besar kepemilikan saham oleh pemerintah dalam perusahaan maka semakin tinggi luas pengungkapan emisi karbon oleh perusahaan manufaktur di Indonesia. Hasil penelitian ini sejalan dengan penelitian (Liu \& Anbumozhi, 2009); (Huang \& Kung, 2010); (Peng et al., 2015) serta Nur Pratiwi, 2017). Temuan penelitian ini juga sejalan dengan teori stakeholders yang menyatakan bahwa perusahaan beroperasi bukan hanya untuk kepentingan sendiri, namun harus memberikan manfaat bagi stakeholder. Sebaliknya, keberadaan suatu perusahaan sangat dipengaruhi oleh dukungan yang diberikan oleh stakeholder kepada perusahaan tersebut. Keterlibatan pemerintah secara langsung dalam kepemilikan saham perusahaan akan memberikan wewenang yang lebih luas bagi pemerintah untuk melakukan pengawasan. Menurut (Peng et al., 2015) tekanan dari regulator (pemerintah) merupakan salah satu faktor utama 
Luh Gede Krisna Dewi, Made Yenni Latrini, dan Ni Nyoman Rsi Respati. Determinan ...

perusahaan peduli terhadap lingkungan dan melakukan pengungkapan emisi karbon. Pemerintah dengan kepemilikan saham yang bersifat mayoritas mampu mengendalikan perusahaan untuk beraktivitas sesuai dengan regulasi yang ada. Perusahaan dengan status BUMN diharapkan mampu menjadi contoh dan memberikan benchmarking mengenai pengungkapan emisi karbon dan peningkatan kualitas energi yang digunakan. Hal menarik dari hasil penelitian ini adalah ada beberapa perusahaan dengan status BUMN memiliki kinerja lingkungan yang sangat sangat baik (peringkat Emas PROPER) namun cenderung sedikit melakukan pengungkapan emisi karbon. Sebaliknya ada beberapa perusahaan melakukan pengungkapan emisi karbon yang memadai namun beberapa site perusahaan mendapatkan peringkat yang tidak terlalu baik (peringkat Biru PROPER). Fenomena ini terjadi disebabkan karena pengungkapan emisi karbon merupakan pengungkapan yang bersifat sukarela (voluntary disclosure) sehingga ada beberapa perusahaan menganggap hal ini tidak terlalu penting dibandingkan hal produktif lainnya. Alasan lain yang mendukung adalah pandangan investor dan kreditur yang lebih memperhatikan faktor-faktor keuangan dalam mengambil keputusan investasi dan pendanaan.

\section{SIMPULAN}

Berdasarkan pemaparan hasil penelitian dalam bab lima maka dapat disimpulkan sebagai berikut Economic pressure tidak berpengaruh pada pengungkapan emisi karbon perusahaan di Indonesia. Economic pressure yang diukur dengan tingkat profitabilitas perusahaan bukan merupakan faktor penentu perusahaan manufaktur 
dalam melakukan pengungkapan emisi karbon di Indonesia. Social pressure tidak berpengaruh pada pengungkapan emisi karbon perusahaan di Indonesia. Social pressure yang diukur dari peringkat PROPER perusahaan bukan merupakan faktor penentu perusahaan manufaktur dalam melakukan pengungkapan emisi karbon di Indonesia. Financial market pressure tidak berpengaruh pada pengungkapan emisi karbon perusahaan di Indonesia. Financial market pressure yang diukur dari tingkat leverage perusahaan bukan merupakan faktor penentu perusahaan manufaktur dalam melakukan pengungkapan emisi karbon di Indonesia. Regulatory pressure berpengaruh positif pada pengungkapan emisi karbon perusahaan di Indonesia. Regulatory pressure yang diukur dari status perusahaan sebagai perusahaan BUMN merupakan faktor penentu perusahaan manufaktur dalam melakukan pengungkapan emisi karbon di Indonesia. Kepemilikan saham pemerintah dalam perusahaan memberikan wewenang pengawasan kepada pemerintah terkait pengungkapan emisi karbon yang lebih luas.

Bagi perusahaan disarankan untuk memberikan perhatian yang lebih besar terkait dengan luas pengungkapan emisi karbon serta lebih mendorong peningkatan kinerja terkait dengan kinerja sosial lingkungan. Memberikan citra ramah lingkungan (green business) kepada masyarakat adalah penting dan harus didukung dengan peningkatan luas pengungkapan emisi karbon. Bagi pemerintah sebagai penyusun standar (standard setter), hasil penelitian ini dapat dijadikan acuan dan pertimbangan dalam menyusun regulasi. Hasil penelitian menemukan bahwa luas pengungkapan emisi karbon pada perusahaan manufaktur di Indonesia 
Luh Gede Krisna Dewi, Made Yenni Latrini, dan Ni Nyoman Rsi Respati. Determinan ...

dipengaruhi oleh keterikatan perusahaan dengan pemerintah sebagai salah satu pemegang saham, sehingga hal ini memberikan pengawasan lebih dalam aktivitas terkait kinerja sosial dan lingkungan. Bagi penelitian berikutnya disarankan untuk menggali lebih dalam faktor-faktor penentu lain yang mampu mempengaruhi pengungkapan emisi karbon perusahaan seperti misalnya karakteristik dewan komisaris dan direksi, penerapan good corporate governance khususnya terkait dengan unsur komite audit dan keberadaan komisaris independen yang akan memberikan pengawasan terhadap aktivitas perusahaan.

\section{REFRENSI}

Anwar, S. N. (2016). Pengaruh Corporate Governance Terhadap Carbon Emission Disclosure. Skripsi.

Bae Choi, B., Lee, D., \& Psaros, J. (2013). An analysis of Australian company carbon emission disclosures. Pacific Accounting Review, 25(1), 58-79. https://doi.org/10.1108/01140581311318968

Berthelot, S., \& Robert, A.-M. (2011). Climate Change Disclosures: An Examination of Canadian Oil and Gas Firms. Issues In Social And Environmental Accounting, 5(2), 106. https://doi.org/10.22164/isea.v5i2.61

Borghei-Ghomi, Z., \& Leung, P. (2013). An Empirical Analysis of the Determinants of Greenhouse Gas Voluntary Disclosure in Australia. Accounting and Finance Research, 2(1). https://doi.org/10.5430/afr.v2n1p110

Cotter, J., \& Najah, M. M. (2012). Institutional investor influence on global climate change disclosure practices. Australian Journal of Management, 37(2), 169-187. https://doi.org/10.1177/0312896211423945

Dawkins, C., \& Fraas, J. W. (2011). Coming Clean: The Impact of Environmental Performance and Visibility on Corporate Climate Change Disclosure. Journal of Business Ethics, 100(2), 303-322. https://doi.org/10.1007/s10551010-0681-0

Deegan, C., \& Unerman, J. (2011). Financial accounting theory. UK Higher Education Business Accounting. 
Freedman, M., \& Jaggi, B. (2005). Global warming, commitment to the Kyoto protocol, and accounting disclosures by the largest global public firms from polluting industries. International Journal of Accounting, 40(3), 215-232. https://doi.org/10.1016/j.intacc.2005.06.004

Freeman, R. E. (1994). The Politics of Stakeholder Theory: Some Future Directions. Business Ethics Quarterly, 4(4), 409-421. https://doi.org/10.2307/3857340

Healy, P. M., \& Palepu, K. G. (2001). Information asymmetry, corporate disclosure, and the capital markets: A review of the empirical disclosure literature. Journal of Accounting and Economics. https://doi.org/10.1016/S0165-4101(01)00018-0

Irwhantoko, I., \& Basuki, B. (2016). Carbon Emission Disclosure: Studi pada Perusahaan Manufaktur Indonesia. Jurnal Akuntansi Dan Keuangan, 18(2). https://doi.org/10.9744/jak.18.2.92-104

Jannah, Richatul. (2014). Analisis Faktor-Faktor yang Mempengaruhi Carbon Emission Disclosure Pada Perusahaan di Indonesia (Studi Empiris pada Perusahaan yang Terdaftar di Bursa Efek Indonesia Periode 2010-2012). Fakultas Ekonomika dan Bisnis, Universitas Diponegoro

Kalu, J. U., Buang, A., \& Aliagha, G. U. (2016). Determinants of voluntary carbon disclosure in the corporate real estate sector of Malaysia. Journal of Environmental Management, 182, 519-524. https://doi.org/10.1016/j.jenvman.2016.08.011

Luo, L., Lan, Y. C., \& Tang, Q. (2012). Corporate Incentives to Disclose Carbon Information: Evidence from the CDP Global 500 Report. Journal of International Financial Management and Accounting, 23(2), 93-120. https://doi.org/10.1111/j.1467-646X.2012.01055.x

Peng, J., Sun, J., \& Luo, R. (2015). Corporate Voluntary Carbon Information Disclosure: Evidence from China's Listed Companies. World Economy, 38(1), 91-109. https://doi.org/10.1111/twec.12187

Peters, G., \& Romi, A. (2009). Carbon disclosure incentives in a global setting: an empirical investigation. University of Arkansas, Fayetteville, AR, Working Paper. Retrieved from http://waltoncollege.uark.edu/acct/ Carbon_Disclosure.doc

Pradini, H. S. (2013). The Analysis of Information Content towards Greenhouse Gas Emissions Disclosure in Indonesia Companies. Diponegoro Journal of Accounting, $2(2), \quad 1-12$. Retrieved from 
Luh Gede Krisna Dewi, Made Yenni Latrini, dan Ni Nyoman Rsi Respati. Determinan ...

http://eprints.undip.ac.id/38737/1/PRADINI.pdf

Prado-Lorenzo, J.-M., Gallego-Alvarez, I., \& Garcia-Sanchez, I. M. (2009). Stakeholder engagement and corporate social responsibility reporting: the ownership structure effect. Corporate Social Responsibility and Environmental Management, 16(2), 94-107. https://doi.org/10.1002/csr.189

Stanny, E., \& Ely, K. (2008). Corporate environmental disclosures about the effects of climate change. Corporate Social Responsibility and Environmental Management, 15(6), 338-348. https://doi.org/10.1002/csr.175

Suhardi, R.P. \& A. Purwanto. (2015). Analisis Faktor-faktor yang Mempengaruhi Pengungkapan Emisi Karbon di Indonesia (Studi Pada Perusahaan yang Terdaftar di Bursa Efek Indonesia Periode 2010-2013). Diponegoro Journal of Accounting, 4(2), 1-13. Retrieved from http://ejournalS1.undip.ac.id/index.php/accounting 